\title{
Assessment of the Regional Knowledge Index for Sustainable Development of Siberian Mining Regions
}

\author{
Sergey Kukushkin ${ }^{1}$, and Oleg Kalenov ${ }^{2, *}$ \\ ${ }^{1}$ Plekhanov Russian University of Economics, Academic Department of Organizational and \\ Managerial Innovations, 117997, Moscow, 36 Stremyanny lane, Russia \\ ${ }^{2}$ Plekhanov Russian University of Economics, Academic Department of Industrial Economics, \\ 117997, Moscow, 36 Stremyanny lane, Russia
}

\begin{abstract}
At present time, the issue of defining indicators of sustainable development corresponds to the processes of modern economy development such as digitalization, technological convergence. They are going to replace mining from GDP of industrial countries and decease environmental pressure by expanding economy of knowledge. For the first time, the knowledge index was calculated by the World Bank. It should be noted that the World Bank calculated the indices for each individual country. This would allow developing the necessary decisions and government policies to build a knowledge economy. This goal is pursued by the authors of the article, but in relation to the sustainable development of the mining regions of Russia. The article discusses various approaches to assessing the regional knowledge index, and proposes a new methodology for its assessment based on the main determinant of the matrix and its logarithm. Based on the proposed methodology, the knowledge index was evaluated, which shows the conditions for the knowledge economy development in the mining regions of Russia. The rating of the mining regions of Siberian Federal District was built. The main conditions affecting the formation of the knowledge economy in the mining regions of Siberia in the context of their sustainable development are identified.
\end{abstract}

\section{Introduction}

The world economic crisis, as history shows, always leads to serious, structural changes in the economy. The last world crisis of 2008-2009 was no exception. One of the most important causes of the crisis, in our opinion, is the transition of the economic system (both global and individual national) to the knowledge economy or the economy of the information society, although there are other reasons [1]. This is important that in this transition the awesome step to sustainable development is expected because knowledge economy can shorten negative affect on environment.

\footnotetext{
*Corresponding author: oekalenov@yandex.ru
} 
The knowledge economy is a system of relations in which knowledge becomes the main factor of production, while capital and labor are a necessary condition. Of course, knowledge itself will not create a material economic good, but they are the basis, the "guarantor" of these same goods. Already today, according to some scientists, when creating consumer goods, knowledge forms up to $60 \%$ of the value of a product from the spent human labor of a person, instead natural resources [2].

\section{Materials and Methods}

For the assessment and the ability of states to create, use and disseminate knowledge, the World Bank in 2004 developed the "Knowledge Assessment Methodology", which consists of four groups of 109 indicators. The developers suggest that this methodology will help states in developing policies for the transition to a knowledge economy. The latest data for calculating the "knowledge economy indices" and "knowledge indexes" were published on the World Bank website in 2012. Therefore now the alignment of knowledge economy indicators to sustainable development potential assessment is of high demand.

According to the developed methodology, expert assessment is given a score (from 0 to 10 points) for each of the groups of indicators:

- the index of economic and institutional development, which shows the conditions in which the national economic system develops: the legal environment; regulation of business and private initiative; the ability of the environment to create goods;

- education index - education of the population and its skills to receive, use and disseminate knowledge;

- innovation index - characterizes the state of the national innovation system;

- Information and Communication Technologies Index - an assessment of the infrastructure capable of effectively disseminating and processing information. The World Bank methodology also involves evaluating two aggregates:

1. Knowledge Economy Index - the country's ability to use knowledge for economic and social development. It is calculated as the average value of four indices: institutional regime; education; innovation; information and communication technology;

2. Knowledge Index - the ability of society to create, use and disseminate knowledge. It is the average of three indicators: education and human resources; innovation; information and communication technology.

With reference to the regional economy, a group of scientists from the Institute for Applied Economic Research of the RANEPA, based on the World Bank's Knowledge Assessment Methodology and the Rosstat database, the Russian Knowledge Index (RKI) was developed [3]:

$$
R K I=\frac{G R P_{g r}+G R p_{c}+S t u d+E d u c+\text { Research }+P C T+M o b+W e b_{c o m p}}{8}
$$

where:

- indicators of the development of the economy and welfare: GRPgr - the growth rate of the gross regional product (GRP), \%; GRPpc - GRP per capita, thous. Rub. per person;

- indicators of education and human capital: Stud - the number of students per 1000 inhabitants; Educ is the average number of years of study for employees;

- indicators of science and innovation: Research - the number of scientific employees per 10,000 inhabitants; $P C T$ - the number of applications for the protection of intellectual property (patents) per 1 million inhabitants;

- information infrastructure indicators: $M o b$ - the number of cell phones per 100 people; Webcomp - the share of workers provided with computers with Internet access, $\%$. 
As the authors of this methodology, the index does not measure the level of the knowledge economy, but only the conditions for its formation. However, this does not diminish the importance of their work.

There are other methods for assessing the development of the knowledge economy. For example, TechnoSuccess Company [4] proposed a method for determining the National rating of high-tech enterprises. This rating describes the results of the innovation economy - the effectiveness of high-tech organizations. To determine the status of research and development, an appropriate methodology was developed by the RANEPA author team under the guidance of N.G. Kurakova [5]. This method allows determining the degree of novelty of a particular development (technology, product, etc.) and making a predictive assessment of environmental changes efficiency. The basis of the calculation is a multicriteria analysis of breakthrough scientific research.

In our proposed methodology for assessing the regional knowledge index, which is also adapted to the national statistical data, the regional knowledge index $(\operatorname{Reg} K I)$ is calculated on the basis of 16 indicators, which are divided into the four groups.

Group I - Dynamics of the development of the region and the well-being of the population without increasing pressure on environment.

A high standard of living and steady growth of GRP are interrelated and mutually influence each other and create conditions for sustainable development in the knowledge economy.

Group II - Education and training system.

Indicators of this group characterize: 1) the educational level of the population of the region and 2) the possibility of obtaining appropriate education. Moreover, they show the possibility of not only obtaining knowledge, but also generating it.

Group III - Innovation potential and science. The indicators of this group show both the generation of new knowledge and its commercial use by organizations in the region, especially to improve environment situation.

IV group - Information infrastructure. Indicators of this group actually show the level of information society. Information and communication technologies are an important technical and technological component of the sustainable development, which is currently being formed.

The dynamics of indicators of this group characterizes the possibility of obtaining and disseminating information and knowledge, both by man and by organization.

The calculation of the knowledge index is carried out in two stages. At the first stage, calculations are carried out using the calculation of the main determinant of the matrix. In our case, we have a $4 \times 4$ square matrix. To calculate the main determinant, the following formula can be used:

$$
\Delta=\sum_{j=1}^{n}(-1)^{1+j} a_{i-1} \overline{M_{1}^{l}}
$$

The determinant of the matrix allows manipulating with its elements, in our case - with economic indicators, regardless of where it is in the row (or column). In this matrix, a row is related indicators that characterize the state of a process or object. The determinant of the matrix shows the influence of each element of the matrix.

At the second stage is the logarithm of the main determinant. Logarithmically, we perform two tasks: 1) removing the extremal differences in the values of the numerical series - statistical data and 2) removing possible errors in the numerical values that could have been made due to the inaccuracy of the measuring instruments used. 


\section{Results and Discussion}

The developed methodology for determining the regional knowledge index (RegKI) is an adapted methodology developed by the World Bank. It takes into account the peculiarities of the Russian economy and the data provided by the national statistical service. Once again, the knowledge index does not measure the level of development of the knowledge economy, but only characterizes the conditions for its formation, accordingly sustainable development imperative.

The methodology developed by the authors was tested on statistical data from Russian regions (regions and federal districts) for the period from 2000 to 2015. The initial data was provided by the Federal State Statistics Service [6]. This article analyzes the formation of the knowledge economy in the regions of the Siberian Federal District (SFD).

As can be seen from the graph shown in Fig. 1, the regional knowledge index for the SFD goes through two stages. The first stage - until 2009 - the period of the Great Recession, RegKI fluctuates at the level of 7.0-7.5 points. Compared with other federal districts (Tab. 1), the Siberian Federal District is in the second half of the list, lagging behind the leaders by 1.5-2.0 points. This indicates that during this period there were insufficient conditions in the district for the formation of the knowledge economy [7].

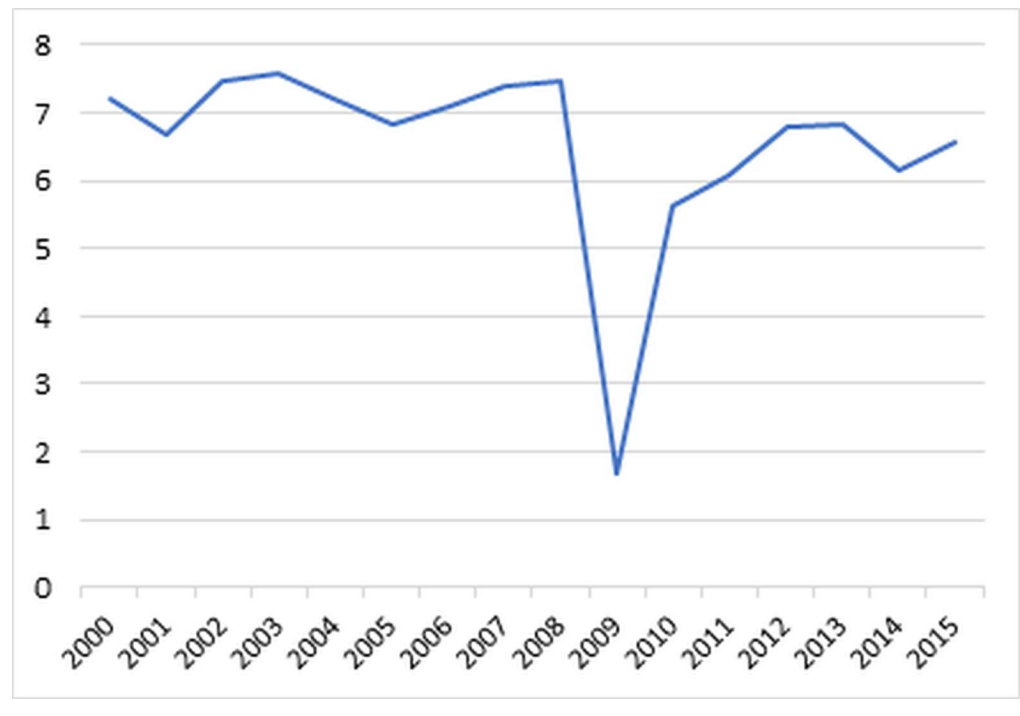

Fig. 1. Dynamics of the knowledge index of the Siberian Federal District for $2000-2015$.

In 2009 (the year of the Great Recession - the global economic crisis) RegKI plummeted to 1.69 . Since 2010, it began to grow, but could not reach the pre-crisis level. For the period 2011-2015 RegKI was about 6.0-6.8 points (Table 1).

Table 1. Regional knowledge index and ranking of federal districts for the period 2012-2015.

\begin{tabular}{|c|c|c|c|c|c|c|c|c|}
\hline & \multicolumn{2}{|c|}{2012} & \multicolumn{2}{|c|}{2013} & \multicolumn{2}{|c|}{2014} & \multicolumn{2}{|c|}{2015} \\
\hline & \begin{tabular}{|c} 
Knowle \\
dge \\
Index \\
\end{tabular} & Rating & \begin{tabular}{|c} 
Knowle \\
dge \\
Index
\end{tabular} & Rating & $\begin{array}{c}\text { Knowle } \\
\text { dge } \\
\text { Index } \\
\end{array}$ & Rating & $\begin{array}{l}\text { Knowled } \\
\text { ge Index }\end{array}$ & Rating \\
\hline $\begin{array}{l}\text { Central } \\
\text { Federal } \\
\text { District }\end{array}$ & 9.05 & 2 & 9.16 & 2 & 9.68 & 1 & 9.59 & 1 \\
\hline
\end{tabular}




\begin{tabular}{|c|c|c|c|c|c|c|c|c|}
\hline $\begin{array}{c}\text { Northwestern } \\
\text { Federal } \\
\text { District }\end{array}$ & 7.72 & 4 & 8.25 & 3 & 7.46 & 5 & 8.05 & 4 \\
\hline $\begin{array}{c}\text { Southern } \\
\text { Federal } \\
\text { District }\end{array}$ & 7.53 & 6 & 7.85 & 5 & 7.72 & 4 & 7.84 & 5 \\
\hline $\begin{array}{c}\text { Volga Federal } \\
\text { District }\end{array}$ & 8.34 & 4 & 7.51 & 6 & 2.71 & 8 & 6.07 & 7 \\
\hline $\begin{array}{c}\text { Ural Federal } \\
\text { District }\end{array}$ & 5.11 & 8 & 5.77 & 8 & 6.28 & 6 & 5.16 & 8 \\
\hline $\begin{array}{c}\text { Siberian } \\
\text { Federal } \\
\text { District }\end{array}$ & 6.80 & 7 & 6.82 & 7 & 6.14 & 7 & 6.55 & 6 \\
\hline $\begin{array}{c}\text { North } \\
\text { Caucasian } \\
\text { Federal } \\
\text { District }\end{array}$ & 9.46 & 1 & 9.70 & 1 & 9.47 & 2 & 8.52 & 3 \\
\hline $\begin{array}{c}\text { Far Eastern } \\
\text { Federal } \\
\text { District }\end{array}$ & 8.62 & 3 & 8.08 & 4 & 8.22 & 3 & 8.63 & 2 \\
\hline
\end{tabular}

It should be noted that SFD was not the leader for the entire analyzed period. Tab. 1 shows the rating of federal districts for the period 2011-2015. As you can see, it always held 6-7 $7^{\text {th }}$ place. Fig. 2 shows the RegKI of federal districts for 2015, which clearly reflects the position of the SFD compared to other federal districts.

Among the leaders for 2011 - 2015 (Tab. 1) were the Central Federal District, which over the years shows a positive trend, and the Far Eastern Federal District. However, their dynamics are negative.

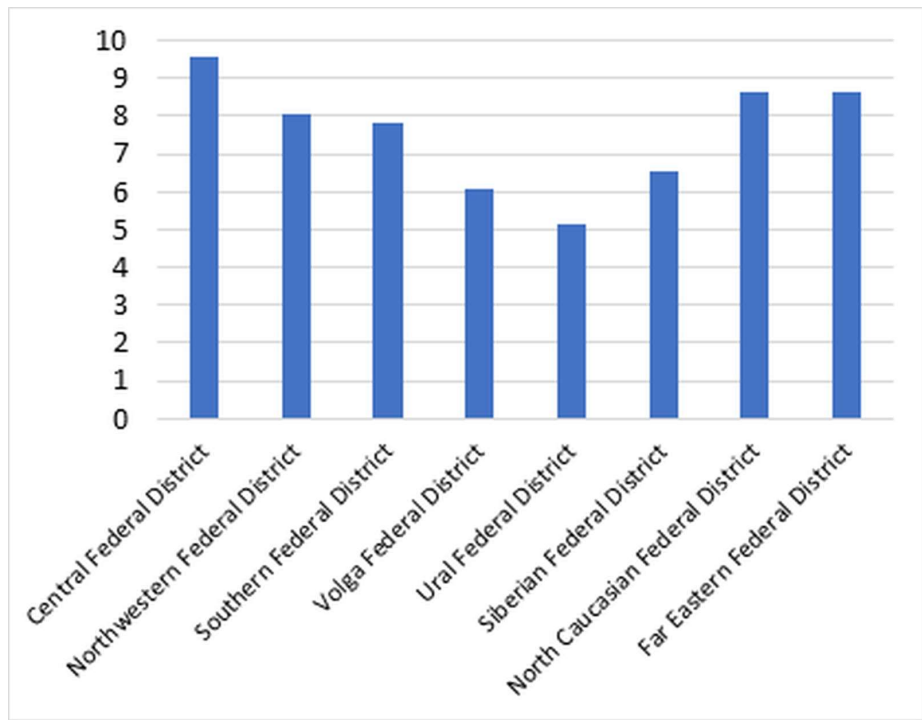

Fig. 2. Regional Knowledge Index 2015.

The low position of the Siberian Federal District is due to the low RegKI regions included in the district. As can be seen from the Tab. 2 in almost all regions of the district, the unstable dynamics of $\operatorname{RegKI}$, the same picture is observed for the entire analysis period 
from 2000 to 2015. The most stable position is observed in the Novosibirsk and Tomsk regions, in which, as is known, there is a significant research base [8]. Historically, these regions have always been among the intellectual and cultural leaders of Siberia [9]. The Trans-Baikal Territory stands out somewhat. In 2011, it was ranked second in Russia, and in subsequent years it makes "jumps", approaching a dozen of leaders, then dropping to the middle.

Table 2. Regional knowledge index and rating of the regions of the Siberian Federal District for $2012-2015$

\begin{tabular}{|c|c|c|c|c|c|c|c|c|}
\hline & \multicolumn{2}{|c|}{$\mathbf{2 0 1 2}$} & \multicolumn{2}{c|}{$\mathbf{2 0 1 3}$} & \multicolumn{2}{c|}{$\mathbf{2 0 1 4}$} & \multicolumn{2}{c|}{2015} \\
\cline { 2 - 10 } & $\begin{array}{c}\text { Knowledge } \\
\text { Index }\end{array}$ & Rating & $\begin{array}{c}\text { Knowledge } \\
\text { Index }\end{array}$ & Rating & $\begin{array}{c}\text { Knowledge } \\
\text { Index }\end{array}$ & Rating & $\begin{array}{c}\text { Knowledge } \\
\text { Index }\end{array}$ & Rating \\
\hline Altai Krai & 3.07 & 91 & 2.21 & 90 & 5.56 & 77 & 3.83 & 92 \\
\hline Republic of Buryatia & 8.43 & 32 & 8.84 & 20 & 8.56 & 22 & 7.52 & 61 \\
\hline Tyva Republic & 0.87 & 94 & 1.85 & 92 & 2.42 & 91 & 4.10 & 89 \\
\hline Republic of Khakassia & 6.94 & 65 & 2.11 & 91 & 3.23 & 89 & 4.33 & 88 \\
\hline Altai Krai & 7.10 & 64 & 8.27 & 34 & 8.30 & 30 & 8.16 & 37 \\
\hline Zabaikalsky Krai & 8.99 & 14 & 8.54 & 24 & 7.20 & 49 & 8.91 & 16 \\
\hline Krasnoyarsk Krai & 7.92 & 45 & 8.23 & 35 & 5.59 & 76 & 7.84 & 45 \\
\hline Irkutsk Oblast & 6.87 & 66 & 5.61 & 77 & 5.77 & 73 & 7.71 & 50 \\
\hline Kemerovo Oblast & 4.82 & 86 & 4.93 & 81 & 4.29 & 81 & 6.95 & 67 \\
\hline Novosibirsk Oblast & 8.80 & 21 & 8.63 & 21 & 6.71 & 63 & 7.96 & 43 \\
\hline Omsk Oblast & 7.60 & 51 & 7.61 & 53 & 7.86 & 36 & 7.60 & 56 \\
\hline Tomsk Oblast & 6.54 & 69 & 8.20 & 37 & 7.13 & 51 & 8.75 & 24 \\
\hline
\end{tabular}

This is confirmed by the graph on Fig. 3. Tomsk region has the second highest rating among the regions of the federal district in 2015. The highest rating of the Trans-Baikal Territory. The most difficult situation in the formation of the knowledge economy is observed in the Republics of Altai and Tyva, these regions are firmly at the end of the rating list.

The situation in the Kemerovo Region, a key mining region of Russia, is somewhat better. Despite the fact that the basis of its GRP is mining, its economy is a place for innovation. The main conductor here is Kuzbass industrial park. Largely due to this, RegKI of the Kemerovo region shows a positive trend. In the period 2011-2015, the region has risen in the ranking from 90 to 67, which indicates an improvement in the conditions for the formation of the knowledge economy [10].

In general, the opinion that was expressed in the works of J. Jacobs [11] and P. Krugman [12], V. Frolova [13], O. Borisova [14] that cities and regions in which large scientific centers whose economies are diversified have better conditions for sustainable development during the knowledge economy formation. The regions that have an agrarian orientation or mono-activities prevail in them, as a rule, have the worst conditions for the formation of a new economy and are among outsiders [15]. 


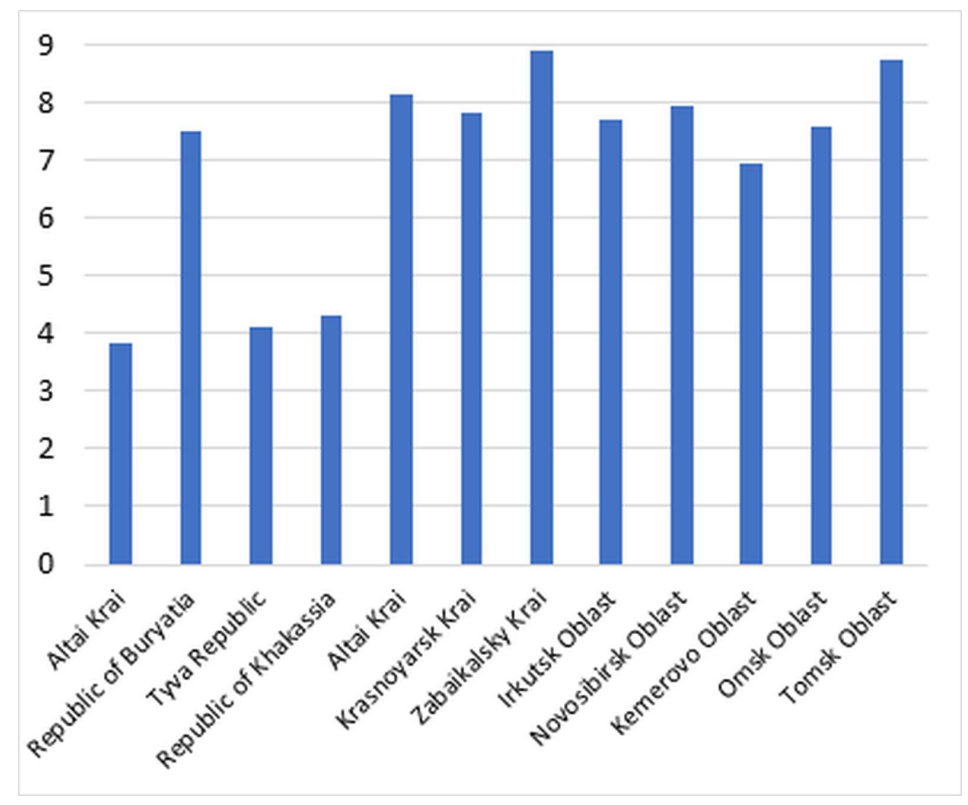

Fig.3. Regional Knowledge Index of the regions of the Siberian Federal District for 2015.

The analysis shows that for the most part the regions of the Siberian Federal District improve the conditions for the formation of the knowledge economy [16]. The highest rates show Zabaikalsky Krai, Novosibirsk and Tomsk regions.

\section{Conclusion}

In conclusion, we would like to note that the methodology proposed by the World Bank, like the methods of other authors, has a significant limitation - a single indicator can significantly affect the RegKI assessment, most often this is the growth of the regional gross product. The method proposed by the authors eliminates this drawback.

At the same time, the application of the methodology developed by the authors shows that the general economic situation has a significant impact on the regional knowledge index. This is evidenced by a sharp drop in the index in 2009 - in the year of the Great Recession. It is not yet possible to establish how the financial sanctions have affected RegKI, since the time period between the Great Recession and the announcement of sanctions is too small. This period just came to recovery from the crisis.

The reported study was funded by RFBR according to the research project №18-010-00325.

\section{References}

1. Yu.R. Tumanyan, O.A Ishenko-Paducova. I.V. Movchan, Terra Economicus. 16:4, 144-153 (2018)

2. C.A. Nordstrem, I. Ridderstrale, Funk Business. Funds dance with talent (Piter, SaintPetersburg, 2003)

3. S.P. Zemtsov, V.M. Komarov, Innovations, 10, 29-38, (2015)

4. I.M. Bortnik, V.A. Barinova, S.P. Zemtsov, S.Yu Infinovskaya, A.V. Sorokina, Innovations, 3, 54-62 (2015) 
5. N.G. Kurakova, V.G. Zinov, L.A. Tsvetkov, O.A. Eremchenko, A.V. Komarova, National science and technology policy of "rapid response": recommendations for Russia (Business Moscow, 2014)

6. Official site of the Federal State Statistics Service of the Russian Federation, URL: http://www.gks.ru/

7. A. Kovalev, N. Rebrova, M. Zhidkova, E3S Web Conf., 41, 04026 (2018)

8. S. Zhironkin, M. Gasanov, G. Barysheva, E. Gasanov, O. Zhironkina, G. Kayachev, E3S Web Conf., 21, 04002 (2017)

9. S. Zhironkin, D. Khloptsov, N. Skrylnikova, I. Petinenko, O. Zhironkina, E3S Web Conf., 41, 04010 (2018)

10. E. Dotsenko, E3S Web Conf., 21, 04013 (2017)

11. J. Jacobs, The Economy of Cities (Random House, New York, 1969)

12. P. Krugman, Development, geography, and economic theory (MIT Press, Cambridge, 1995)

13. V. Frolova, O. Dolina, T. Shpilkina, E3S Web Conf., 41, 04027 (2018)

14. O. Borisova, V. Frolova, M. Livson, V. Biryukov, E3S Web Conf., 41, 04028 (2018)

15. E. Dotsenko, N. Ezdina, E3S Web Conf., 41, 04048 (2018)

16. E. Shavina, O. Kalenov, E3S Web Conf., 21, 04025 (2017) 